\title{
ISOLATION AND TRANSLATION OF HORDEIN MESSENGER RNA FROM WILD TYPE AND MUTANT ENDOSPERMS IN BARLEY
}

\author{
by \\ ANDERS BRANDT and JOHN INGVERSEN \\ Agricultural Research Department, Risø National Laboratory, DK-4000 Roskilde \\ and \\ Department of Physiology, Carlsberg Laboratory, \\ Gamle Carlsberg Vej 10, DK-2500 Copenhagen Valby
}

Keywords: hordein precursor, high lysine mutant, prolamin

\begin{abstract}
Messenger RNA has been isolated from developing barley endosperms by sucrose gradient sedimentation, Sepharose $4 \mathrm{~B}$ gel filtration and preparative gel electrophoresis. Hordein messenger RNA was found to be a major constituent of the total messenger RNA population of the endosperm cell. Polyadenylated hordein messenger RNA sedimented at $11 \mathrm{~S}$ in sucrose gradients and electrophoretic analysis reveals the presence of at least three RNA species with apparent molecular weights of $0.45,0.36$ and 0.30 megadaltons. The $11 \mathrm{~S}$ messenger RNA was translated in vitro into hordein precursor polypeptides which are 2-4 kilodaltons larger than the native hordein polypeptides. The endosperm cell of mutant No. 1508 contained twice as much RNA as the wild type endosperm cell but the same amount of polyadenylated IIS RNA. The template activity of the latter was $10 \%$ of that found for the 11S hordein messenger RNA from the wild type and was limited to translation into one hordein precursor polypeptide.
\end{abstract}

\section{INTRODUCTION}

The prolamine storage protein of the barley endosperm, termed hordein, is preferentially synthesized in the developing kernel 15-25 days after fertilization (6). The hordein polypeptides are synthesized on polyribosomes bound to the endoplasmic reticulum $(7,17)$, and transferred across the membrane into its lumen (10). From there they are transported into the vacuoles and deposited in protein bodies $(26,31)$. In a short period of time the barley endosperm cells thus carry out a large scale synthesis and transport of hordein. High levels of messenger RNA's coding for hordein polypeptides can be expected to be present in the endosperm cells $15-25$ days after fertilization.

In vitro synthesis of specific plant proteins with the aid of isolated RNA or DNA templates has recently been achieved for the small and large subunits of ribulose 1,5-bisphosphate 
carboxylase $(11,13,15,20,22,24)$ light harvesting chlorophyll $\mathrm{a} / \mathrm{b}$ protein (1), phenylalanine ammonia lyase (36), leghaemoglobin (41), globulin-1 storage protein (19) and zein $(8,30)$. With such experiments it is possible to determine the cellular site of synthesis of a protein, the location of the gene coding for its primary structure or the nature of a mutant. Zein, the small subunit of ribulose 1,5-bisphosphate carboxylase, and the light harvesting chlorophyll $\mathrm{a} / \mathrm{b}$ protein are apparently synthesized as larger sized precursors which are subsequently processed in connection with their transport to other cell compartments.

Single gene mutations exist in barley, which affect the synthesis of hordein in the endosperm. One such mutant, the high lysine mutant Ris $\varnothing$ No. 1508, synthesizes only $20 \%$ of the amount of hordein found in the wild type endosperm $(6,27)$. Isolated polysomes from this mutant produced only small amounts of hordein (7). Allelic differences for hordein polypeptide patterns in electropherograms are determined by two loci on chromosome $5(32,39)$, whereas the gene mutated in No. 1508 is located on chromosome $7(29,40)$.

In order to study the synthesis of hordein in the barley endosperm and to gain an insight into the nature of the mutation No. 1508, we have isolated messenger RNA coding for the hordein polypeptides using Poly(U)-Sepharose affinity chromatography, Sepharose 4B chromatography, preparative gel electrophoresis and sucrose gradient sedimentation. This paper describes the partial purification of the hordein messenger RNA molecules and gives evidence for their translation into larger sized precursors of hordein polypeptides. Some characteristics of the RNA from the mutant are given.

\section{MATERIALS AND METHODS}

\subsection{Chemicals}

Micrococcus nuclease (E.C. No. 3.2.4.7), RNAase A (E.C. No. 3.1.4.22), t-RNA mixture (Type I) and spermidine-phosphate were obtained from Sigma Chemicals. $\mathrm{CsCl}$ (Supra-
purR) and phenol from Merck. Phenol was redistilled before use. E.coli ribosomal RNA was purchased from Miles Laboratories, Poly(U)Sepharose 4B from Pharmacia and Oligo(dT)cellulose from Collaborative Research. ${ }^{3} \mathrm{H}$-polyuridylic acid (specific activity 20-74 Ci.mmole ${ }^{-1}, 41-147$ nucleotide residues) was obtained from Radiochemical Center, Amersham.

\subsection{Plant materials}

Barley plants (Hordeum vulgare $\mathrm{L}$ ) cv. Bomi and its mutant Ris $\emptyset$ No. 1508 were either field grown or grown in a growth chamber as described previously (10). Spikes were harvested 20 days after anthesis. If spikes were not to be used immediately after harvest, they were placed in polyethylene bags, frozen in liquid nitrogen and stored at $-70^{\circ} \mathrm{C}$. Stored plant material was used within 3 months after harvest.

\subsection{Isolation of membrane bound polyribosomes}

Membrane bound polyribosomes were isolated by a procedure which was modified from that previously described (7) in the following manner: The initial $500 \times \mathrm{g}$ centrifugation was omitted, which improved the yield of membrane bound polysomes two-fold, $\mathrm{K}$ - and $\mathrm{Mg}$-salts were present as acetates and beta-mercaptoethanol was replaced with $2 \mathrm{~mm}$-dithiothreitol in the buffers. Analysis of the polysomes was performed in linear 0.3-1.0 M-sucrose gradients made in a solution containing $0.05 \mathrm{M}$-Tris, $\mathrm{pH}$ 7.5, $0.1 \mathrm{M}-\mathrm{KCl}, 0.01 \mathrm{M}-\mathrm{Mg}$-acetate and 0.002 $\mathrm{M}$-betamercaptoethanol. Centrifugation was for $3 \mathrm{hrs}$ at $65,000 \times \mathrm{g}_{\mathrm{av}}$ in a Spinco S.W. 25 rotor.

\subsection{Extraction of total cellular and membrane bound RNA}

RNA extractions were performed essentially as described by AvIV and LeDER (3). Total cellular RNA was extracted from $25 \mathrm{~g}$ endosperms (fresh weight) by homogenization in $60 \mathrm{ml} 0.1$ M-TRIS, $0.1 \mathrm{M}-\mathrm{NaCl}, 0.01 \mathrm{M}$-EDTA pH 9.0 at 
$0^{\circ} \mathrm{C}$ with mortar and pestle. The suspension was further homogenized five times for 30 seconds in a Potter-Elvehjem homogenizer operated at 3,000 r.p.m. SDS was added to give a concentration of $1 \%$ and the homogenate brought to room temperature for 10 minutes. The homogenate was then centrifuged at $10,000 \times \mathrm{g}$ for 10 minutes at $2^{\circ} \mathrm{C}$. An equal part of a solution of phenol:chloroform:isoamylalcohol (50:50:1 $\mathrm{v} / \mathrm{v} / \mathrm{v}$ ) was added to the supernatant, whereafter the mixture was shaken for 10 minutes at room temperature and cooled to $4^{\circ} \mathrm{C}$ before the phases were separated by centrifugation at $10,000 \times \mathrm{g}$ for 5 minutes at $4^{\circ} \mathrm{C}$. The organic lower phase was re-extracted with an equal volume of buffer. The aqueous phases were combined and extracted twice with a mixture of 24 parts of chloroform and 1 part of isoamylalcohol $(\mathrm{v} / \mathrm{v})$. To the final aqueous phase, which contained most of the DNA and RNA of the endosperm, was added solid $\mathrm{CsCl}$ to give a concentration of $1 \mathrm{mg} \cdot \mathrm{ml}^{-1}$. After the $\mathrm{CsCl}$ had dissolved the extract was layered on a solution of 5.7 $\mathrm{M}-\mathrm{CsCl}$ in $0.1 \mathrm{M}$-EDTA (18). After centrifugation at $65,000 \times \mathrm{g}_{\mathrm{av}}$ for $18 \mathrm{hrs}$ at $20^{\circ} \mathrm{C}$ in a Spinco S.W. 25 rotor, a clear pellet of RNA was obtained. Alternatively the nucleic acid was precipitated from the aqueous phase by addition of two volumes of ethanol. After storage over night at $-20^{\circ} \mathrm{C}$, the nucleic acids were collected by centrifugation at $10,000 \times \mathrm{g}$ for 10 minutes, redissolved in $50 \mathrm{mM}$-TRIS, $1 \mathrm{mM}$ EDTA pH 7.5 and $\mathrm{NaCl}$ added to a final concentration of $3 \mathrm{M}$. RNA was precipitated by storage at $4^{\circ} \mathrm{C}$ for $18 \mathrm{hrs}$ and collected by centrifugation at $10,000 \times \mathrm{g}$ for 10 minutes.

\subsection{Cell free protein synthesis}

A wheat germ extract was prepared according to ROBERTS and PATTERSON (37) omitting the pre-incubation step. Endogenous wheat germ template activity was destroyed by treating the extract with Micrococcus nuclease (35). The standard reaction mixture was as described previously (10), but contained $1.8 \mathrm{mM}-\mathrm{Mg}$ acetate, $80 \mathrm{mM}$-K-acetate and $0.4 \mathrm{mM}$-spermidine-phosphate (2). TCA precipitable and isopropanol soluble polypeptides were prepared for electrophoresis as described pre- viously (10) and were analyzed on $12.5 \%$ SDSpolyacrylamide slab gels using the buffer system of CHUA and BENNOUN (12). The gels were processed for fluorography by the procedure of BONNER and LASKEY (4).

\subsection{Poly(U)-Sepharose $4 B$ and oligo(dT)- cellulose affinity chromatography}

Small columns of pre-swollen beads were prepared in pasteur pipettes. The Poly(U)Sepharose 4B columns were washed with ten volumes of $0.7 \mathrm{M}-\mathrm{NaCl}, 10 \mathrm{mM}$-TRIS pH 7.5, five volumes of $90 \%$ formamide and ten volumes of $0.7 \mathrm{M}-\mathrm{NaCl}, 10 \mathrm{mM}$-TRIS pH 7.5 before the RNA sample in $0.7 \mathrm{M}-\mathrm{NaCl}, 10$ mM-TRIS pH 7.5 was applied to the columns. The columns were washed with the $0.7 \mathrm{M}-\mathrm{NaCl}$ buffer until all material absorbing at $260 \mathrm{~nm}$ had eluted. The retained material was eluted with $90 \%$ formamide. The RNA was ethanol precipitated. Oligo(dT)-cellulose columns were washed with $0.7 \mathrm{M}-\mathrm{NaCl}$ buffer, two volumes of $\mathrm{H}_{2} \mathrm{O}$, three volumes of $0.1 \mathrm{M}-\mathrm{NaOH}$ and five volumes of the $0.7 \mathrm{M}-\mathrm{NaCl}$ buffer before the RNA was applied in the $0.7 \mathrm{M}-\mathrm{NaCl}$ buffer. The columns were washed with the $0.7 \mathrm{M}-\mathrm{NaCl}$ buffer until no more material absorbing at $260 \mathrm{~nm}$ had eluted. The polyadenylated fraction was eluted with water.

\subsection{Sucrose gradient sedimentation}

RNA samples heated for 10 minutes at $60^{\circ} \mathrm{C}$ were layered on a 5-20\% linear sucrose gradient prepared with a solution containing 10 mM-TRIS, 1 mM-EDTA, 1\% SDS pH 7.5. Sedimentation was for $18 \mathrm{hrs}$ at $20^{\circ} \mathrm{C}$ at $151,000 \times$ $\mathrm{g}_{\mathrm{av}}$ in a Spinco S.W. 40 rotor. RNA in the collected fractions was precipitated with ethanol. When the fractions contained only small amounts of RNA, $t$-RNA was added as carrier.

\subsection{RNA gel electrophoresis}

RNA gel electrophoresis was carried out in composite $0.7 \%$ agarose- $2.5 \%$ polyacrylamide slab gels according to PEACOCK and DingmaN (33) using a $10 \mathrm{mM}$-Na-phosphate buffer, $\mathrm{pH}$ 7.0. The low ionic strength buffer was re-circu- 
lated during the electrophoresis. RNA samples were denatured in $50 \%$ dimethyl sulfoxide by heating at $60^{\circ} \mathrm{C}$ for 10 minutes before the electrophoresis. The latter was carried out at 30 $\mathrm{mA}$ for $4.5 \mathrm{hrs}$ at $4^{\circ} \mathrm{C}$. Gels were stained with $0.2 \%$ methylene-blue in $0.4 \mathrm{M}-\mathrm{Na}$-acetate $\mathrm{pH}$ 4.7 and destained in $\mathrm{H}_{2} \mathrm{O}$. Ethidium bromide staining was performed with a solution containing $2 \mu \mathrm{g} \cdot \mathrm{ml}^{-1}$ in $0.5 \mathrm{M}-\mathrm{NH}_{4}$-acetate.

\subsection{Extraction of RNA from agarose-polyacrylamide gels}

Gel slices were extracted with $0.1 \mathrm{M}-\mathrm{NaCl}$, 0.05 M-TRIS, 0.005 M-EDTA pH 7.4 by grinding with a teflon coated pestle (25). SDS was added to give a final concentration of $1 \%$. One volume of buffer saturated phenol was added, the mixture shaken and kept over night at $4^{\circ} \mathrm{C}$. The phases were separated by centrifugation at $10,000 \times g$ for 10 minutes and the lower phenol phase re-extracted with the buffer. The combined aqueous phases were extracted two times with chloroform:isoamylalcohol 24:1 (v/v), $\mathrm{NaCl}$ added to a final concentration of $0.7 \mathrm{M}$, and the solution applied to a $1 \mathrm{ml}$ oligo(dT)-cellulose column. Bound RNA was eluted as described under 2.6 .

\subsection{Hybridization of RNA to ${ }^{3} \mathrm{H}$-polyuridylic acid}

RNA was hybridized to $80 \mathrm{nCi}{ }^{3} \mathrm{H}$-polyuridylic acid (specific activity $1.63 \mathrm{mCi} \cdot \mathrm{mg}^{-1}$ ) in $0.5 \mathrm{M}-\mathrm{NaCl}, 10 \mathrm{mM}-\mathrm{TRIS}, 1 \mathrm{mM}-\mathrm{MgCl}_{2} \mathrm{pH} 7.0$ at $28^{\circ} \mathrm{C}$ for 15 minutes (38). The hybridization mixture was diluted ten-fold with the hybridization buffer and single stranded RNA was digested with $20 \mu \mathrm{g}$ pancreatic RNAase A at $28^{\circ} \mathrm{C}$ for 15 minutes. $0.5 \mathrm{mg}$ bovine serum albumin was added and the RNAase resistent RNA-poly(U) hybrids were precipitated with $10 \% \mathrm{TCA}$ at $0^{\circ} \mathrm{C}$ for 30 minutes. The hybrids were collected on glass fiber filters and counted in Omnifluor-toluene (New England Nuclear).

\subsection{Sepharose $4 B$ chromatography of RNA}

A $1.5 \times 30 \mathrm{~cm}$ column was packed with Sepharose 4B equilibrated with $0.1 \mathrm{M}-\mathrm{Na}$-ace- tate, $0.001 \mathrm{M}$-EDTA pH 5.0. RNA samples in the column buffer heated for 2 minutes at $70^{\circ} \mathrm{C}$ and quickly cooled to $4^{\circ} \mathrm{C}$ were applied to the Sepharose 4B column. The column was eluted at $6 \mathrm{ml} \cdot \mathrm{h}^{-1}$ and the absorbance at $254 \mathrm{~nm}$ was measured continuously. Three ml fractions were collected and the RNA precipitated with ethanol.

\section{RESULTS}

\subsection{Amounts and distribution of cellular RNA in wild type and mutant endosperms}

Sucrose gradient centrifugation of initially membrane bound polyribosomes from the two genotypes resulted in profiles as exemplified in Figure 1. A large UV absorbing peak representing monosomes is observed together with six minor peaks corresponding to polyribosomes. Mutant No. 1508 endosperms yielded fewer polysomes ranging from dimers to heptamers than Bomi endosperms. Correspondingly the

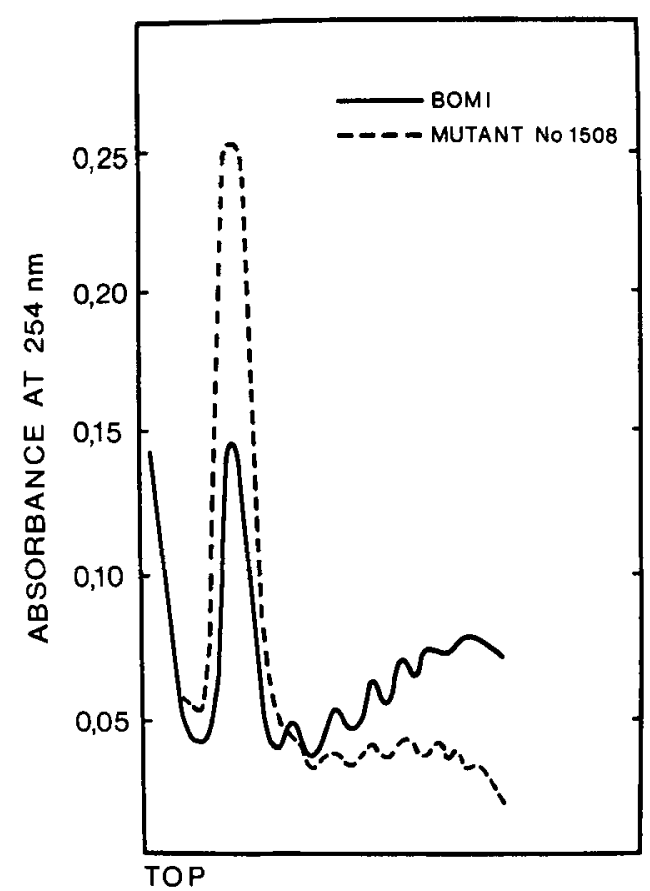

Figure 1. Sucrose density gradient profile of membrane bound polysomes isolated from Bomi and mutant No. 1508 endosperms and separated on $0.3-1.0 \mathrm{M}$-sucrose gradients. 
Table I

Yield of RNA ( $\mu \mathrm{g}$ in 100 endosperms) obtained in polysomal and total cellular extracts from endosperms of wild type and mutant barley. RNA was extracted from polysomes and from the endosperm as described in Materials and Methods $(2.3 ; 2.4)$. The amount of RNA was calculated using an extinction coefficient $\mathrm{E}_{\mathbf{2 6 0}}^{0.1 \%}=\mathbf{2 5}$.

\begin{tabular}{lccc}
\hline Genotype & \multicolumn{2}{c}{ Polysomes } & Total cells \\
& $\begin{array}{c}\text { membrane- } \\
\text { bound }\end{array}$ & free & \\
\hline Bomi & 400 & 240 & 1060 \\
Mutant No. 1508 & 300 & 320 & 2240 \\
\hline
\end{tabular}

mutant preparations were richer in monosomes. This implies that there are either fewer initially membrane bound polysomes in the mutant No. 1508 than in wild type or the polysomes are less stable.

As can be seen from Table I about the same amount of RNA is found in the initially membrane bound polysomes of wild type and mutant endosperm. A similar amount is recovered from the free polysomes in the two genotypes. Two times more total cellular RNA is obtained from the mutant endosperm than from the wild type, a difference which is not expressed in the yields of the RNA from the polysomes.

Analysis of the RNA from the initially membrane bound polysomes and monosomes in sucrose gradients resulted in two broad peaks with maxima at $18 \mathrm{~S}$ and $26 \mathrm{~S}$ indicative of the RNAs of the small and large subunits from cytoplasmic ribosomes (Figures $2 \mathrm{~A}, \mathrm{~B}$ ). In most preparations from Bomi endosperms, the $26 \mathrm{~S}$ peak was larger than the $18 \mathrm{~S}$ peak, whereas in the mutant the $26 \mathrm{~S}$ peak was equal to or lower than the $18 \mathrm{~S}$ peak.

\subsection{Isolation of messenger RNA}

Polyadenylated RNA was obtained by Poly(U)-Sepharose 4B affinity chromatography and tested in the wheat germ cell free protein synthesizing system. Both polyadenylated and non-polyadenylated RNA had optimum template activity in the presence of 1.8
$\mathrm{mM}^{-\mathrm{Mg}^{2+}}$ and $80 \mathrm{~mm}-\mathrm{K}^{+}$. A $10-30$ fold stimulation of protein synthesis was obtained at saturating levels of RNA. For non-polyadenylated RNA from initially membrane bound polysomes, $40 \mu \mathrm{g}$ of RNA were necessary for maximum activity, whereas only $4 \mu \mathrm{g}$ of adenylated RNA resulted in maximum activity (Figure 3).

In Bomi barley (Table II) the polyadenylated fraction of the total RNA reveals a 137-fold higher specific template activity than the nonpolyadenylated fraction. An equivalent increase in the specific template activity is observed for the polyadenylated fraction of the RNA derived from the membrane bound polysomes. As will be shown below (3.3.) the two types of polyadenylated RNAs gave the same
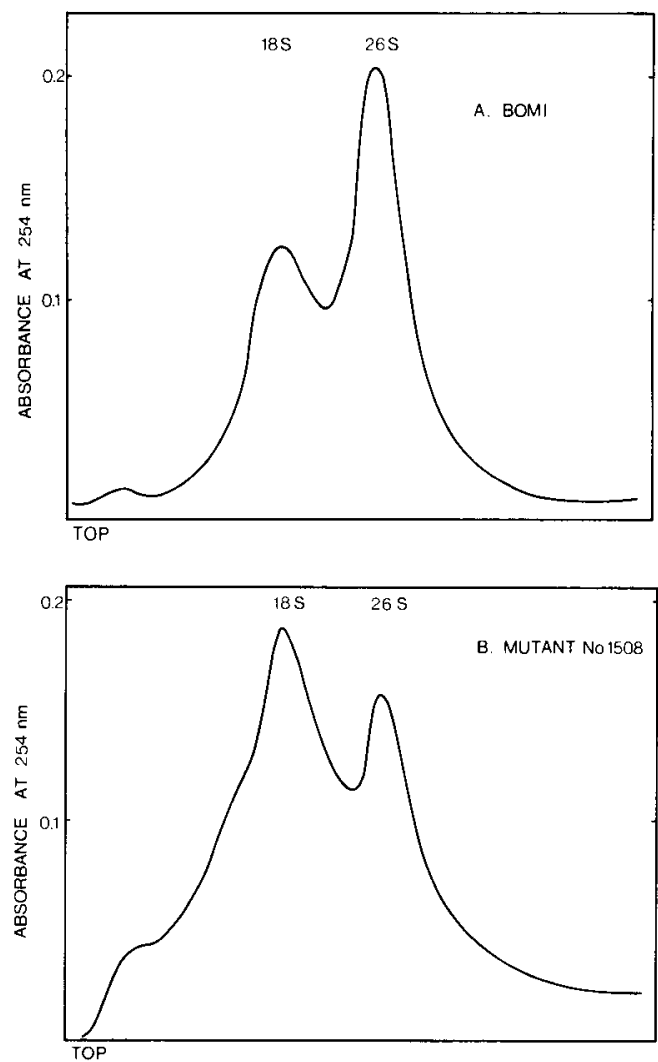

Figure 2. Sedimentation profile of RNA isolated from the pellet of membrane bound polysomes prepared as described under Materials and Methods 2.7.

A: Endosperm RNA from Bomi

B: Endosperm RNA from mutant No. 1508 


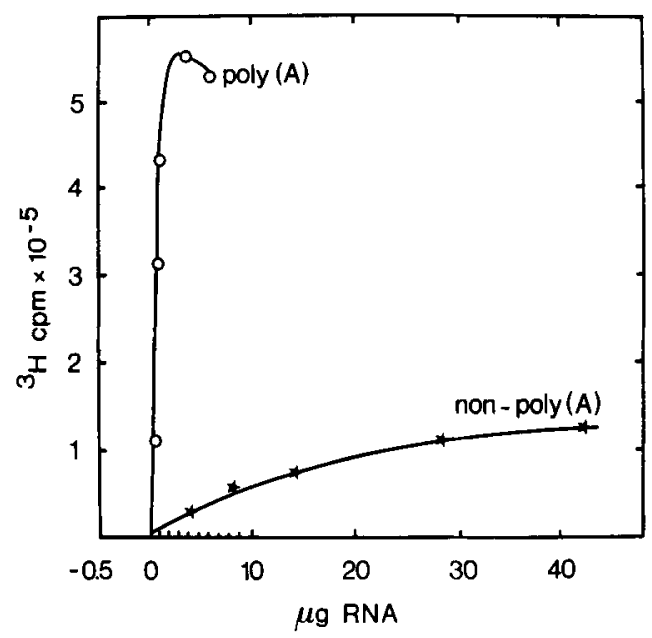

Figure 3. Incorporation of ${ }^{3} \mathrm{H}$-leucine into material insoluble in $10 \%$ hot TCA. The cell free protein synthesizing system was directed by polyadenylated and non-polyadenylated RNA isolated from membrane bound polyribosomes of Bomi endosperms.

translation products. The isolation of polyadenylated RNA via polysomes is less efficient than isolation of this RNA directly from the total cellular RNA. The $4 \mu \mathrm{g}$ of polyadenylated RNA obtained from the polysomes is probably only a fraction of that present in vivo. Therefore it could well be that most of the $10 \mu \mathrm{g}$ of polyadenylated messenger RNA found in the total cellular RNA is derived from membrane bound polysomes.

In mutant No. 1508 (Table II) the specific template activity of both the total RNA and the polysome derived RNA is only $15-20 \%$ of that of the wild type. The specific template activity of the polyadenylated fraction of the total RNA is low compared to wild type. The 340 fold increase in specific template activity over the non-polyadenylated RNA fraction reveals that the large amount of RNA in the mutant is mostly without terminal poly(A) sequences. On the other hand, the polyadenylated fraction of the polysome derived RNA is of the same magnitude as in the wild type. The specific template activity of this RNA in the mutant, however, is poor. This provides evidence that mutant No. 1508 contains considerable amounts of untranslatable polyadenylated messenger RNA.
RNA extracted from the initially membrane bound polysomes from Bomi endosperm was fractionated by sepharose 4B gel filtration and the fractions analyzed for the amount of polyadenylated RNA as well as for template activity. As seen in Figure 4 the major part of the RNA was separated from the polyadenylated RNA which also was most active as template for isopropanol soluble polypeptides.

A separation of the polyadenylated RNA into different molecular species was attempted by sucrose gradient sedimentation. The RNA retained by poly(U)-sepharose $4 \mathrm{~B}$ chromatography amounted to about $1 \%$ of the total cellular RNA (cf. Table III), most of which is ribosomal RNA. Figure 5 illustrates that the $18 \mathrm{~S}$ and $26 \mathrm{~S}$ ribosomal RNA could be separated from an 11S polyadenylated RNA fraction of Bomi endosperms by sucrose gradient sedimentation. This RNA fraction contained more template activity than the other fractions and its specific activity was 8 fold higher than that of polyadenylated RNA (Table III). Allthough a

Table II

Messenger RNA activity in the polyadenylated and nonpolyadenylated RNA fractions of membrane bound polysomal and total cellular extract. The RNA fractions were obtained by poly $(U)$ Sepharose $4 B$ chromatography. Messenger RNA activities were measured in the wheat germ cell free protein synthesizing system using ${ }^{35} \mathrm{~S}$-methionine as label.

\begin{tabular}{lrr}
\hline & $\begin{array}{c}\text { RNA in } \mu \mathrm{g} \text { per } \\
\text { 100 endosperms }\end{array}$ & $\begin{array}{c}\text { specific activity } \\
\text { cpm } \times 10^{-3} \mu \mathrm{g} \\
\text { RNA }^{-1}\end{array}$ \\
\hline Bomi cells & 1200 & 5 \\
non-poly(A) & 1165 & 2 \\
poly(A) & 10 & 275 \\
polysomes & 415 & 5 \\
non-poly(A) & 405 & 2 \\
poly(A) & 4 & 300 \\
Mutant 1508 cells & 2380 & \\
non-poly(A) & 2350 & 0.8 \\
poly(A) & 5 & 0.4 \\
polysomes & 325 & 135 \\
non-poly(A) & 315 & 1 \\
poly(A) & 3 & 0.3 \\
\hline
\end{tabular}




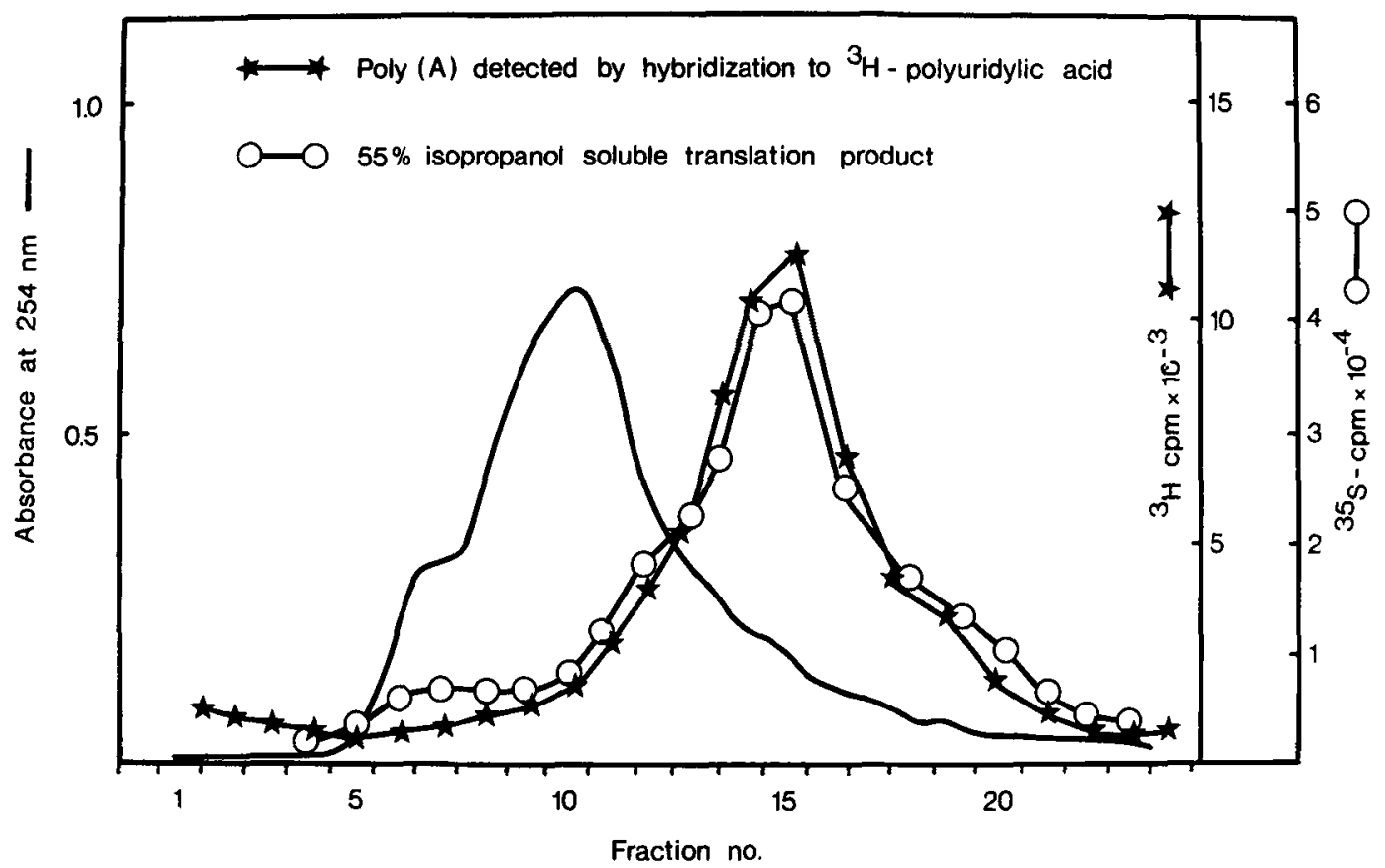

Figure 4. Sepharose 4B chromatography of RNA isolated from initially membrane bound polyribosomes of Bomi endosperms. Messenger RNA was identified as polyadenylated RNA and by its template activity for synthesis of $55 \%$ isopropanol soluble polypeptides. The major absorbance peak signifies column fractions containing large amounts of ribosomal RNA.

polyadenylated fraction could also be separated from ribosomal RNA in a comparable experiment with mutant No. 1508 it had low messenger RNA activity (figure 5).

\subsection{Polypeptides coded for by the messenger RNA fractions}

Endogenous template activity of the wheat germ extract could be destroyed by treat- ment with Micrococcus nuclease and subsequent removal of the nuclease activity by complexing $\mathrm{Ca}^{++}$with EGTA. No labelled polypeptides were detectable when such a wheat germ extract was used in the reaction mixture for cell free protein synthesis without added messenger RNA (cf. Figure 7, track 1).

Total cellular RNA from wild type endosperm coded for a considerable number of ${ }^{35} \mathrm{~S}$-methionine labelled polypeptides (Figure 6,

\section{Table III}

Purification of the barley endosperm $11 S$ messenger RNA fraction. Messenger RNA activity was determined in the wheat germ cell free protein synthesizing system. Poly(A) RNA = poly(U) Sepharose retained RNA. IIS RNA = poly (A) containing RNA sedimenting at 11S. Yield was calculated as $\mu \mathrm{g}$ RA x specific mRNA activity.

\begin{tabular}{|c|c|c|c|c|}
\hline & $\mu \mathrm{g}$ & $\begin{array}{c}\text { Specific template } \\
\text { activity cpm } \times 10^{-3} \\
\mu \mathrm{g} \mathrm{RNA} \mathrm{R}^{-1}\end{array}$ & purification & yield $\%$ \\
\hline Total cell RNA & 6720 & 5 & 1 & 100 \\
\hline $\operatorname{poly}(A)$ RNA & 60 & 275 & 55 & 49 \\
\hline 11S RNA & 7 & 2175 & 435 & 43 \\
\hline
\end{tabular}


A. Brandt \& J. Ingversen: Hordein m RNA
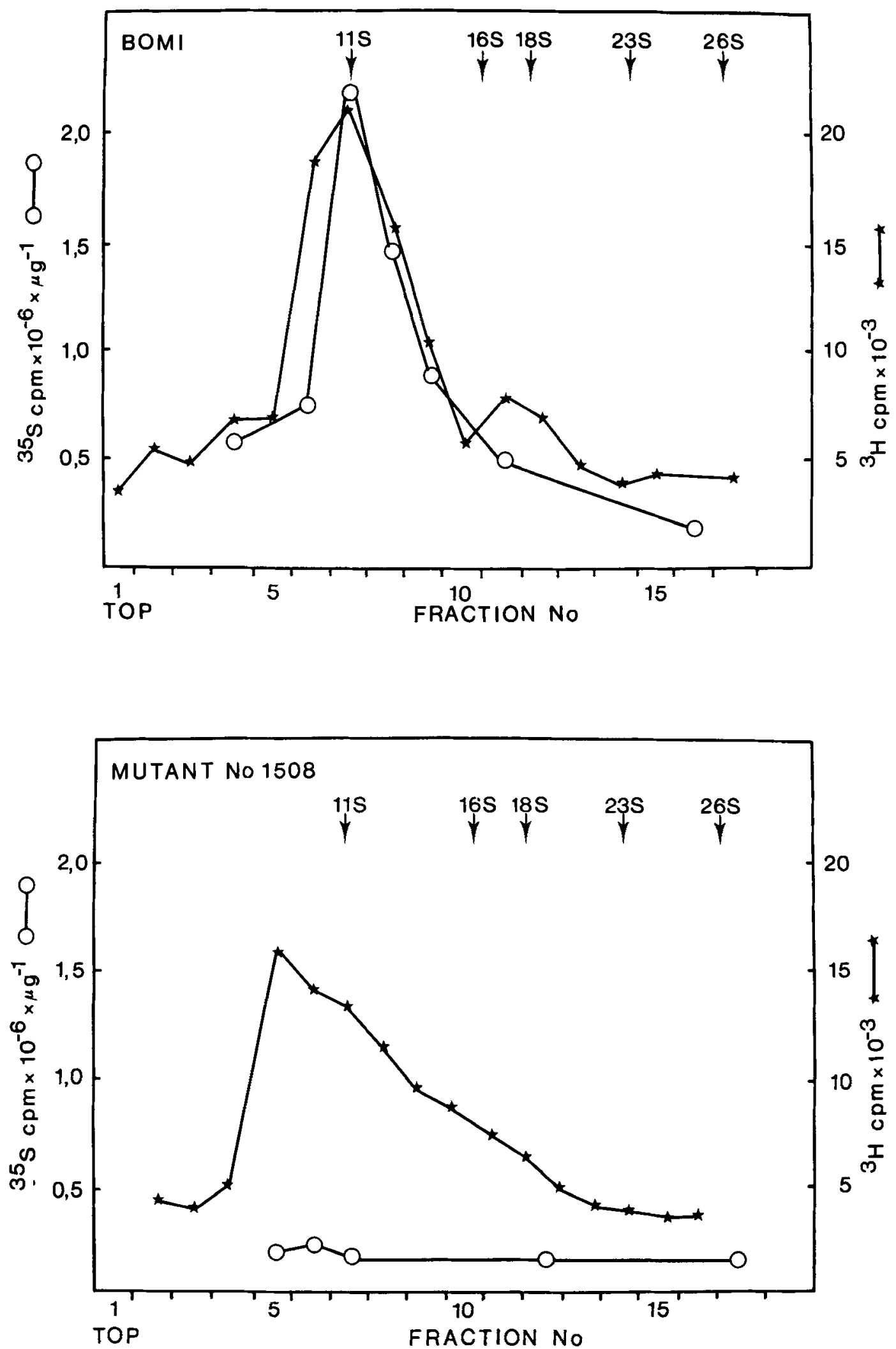
track 2). These include polypeptides with apparent molecular weights larger than, equal to and smaller than those of in vivo labelled hordein (Figure 6, track 1). The fluorogram

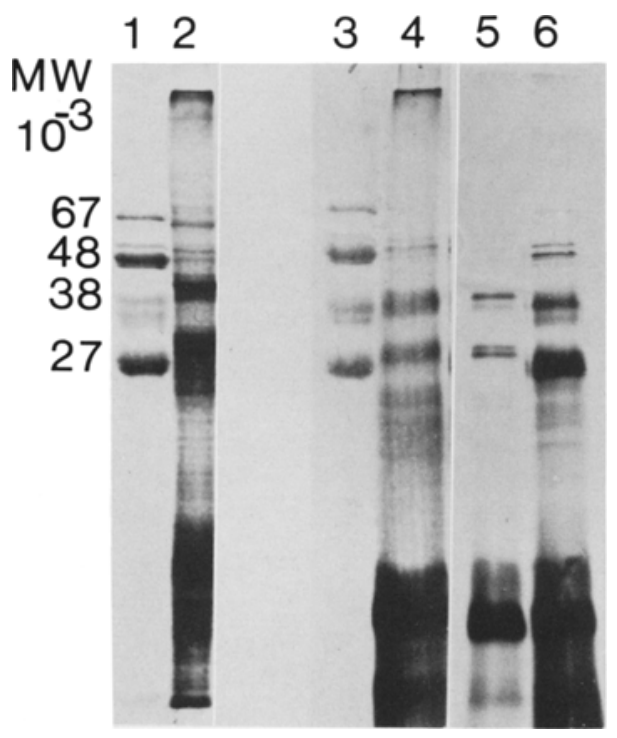

Figure 6. Fluorograms of translation products of mRNA isolated from Bomi endosperms. The molecular weights refer to some characteristic hordein polypeptides synthesized in vivo. Pairs originating from the same electrophoretic run are: Tracks 1 and 2 ; tracks 3 and 4 ; tracks 5 and 6.

Track 1 : In vivo ${ }^{14} \mathrm{C}$-labelled hordein marker polypeptides.

Track 2: In vitro ${ }^{35} \mathrm{~S}$-methionine labelled polypeptides synthesized with total cellular endosperm RNA.

Track 3: In vivo ${ }^{14} \mathrm{C}$-labelled hordein marker polypeptides.

Tracks 4 and 5: In vitro ${ }^{35} \mathrm{~S}$-methionine labelled polypeptides made with $11 \mathrm{~S}$ polyadenylated RNA as template and extracted with 55\% isopropanol.

Track 6: In vitro ${ }^{35} \mathrm{~S}$-methionine labelled polypeptides made with initially membrane bound polysomes as template and extracted with $55 \%$ isopropanol.

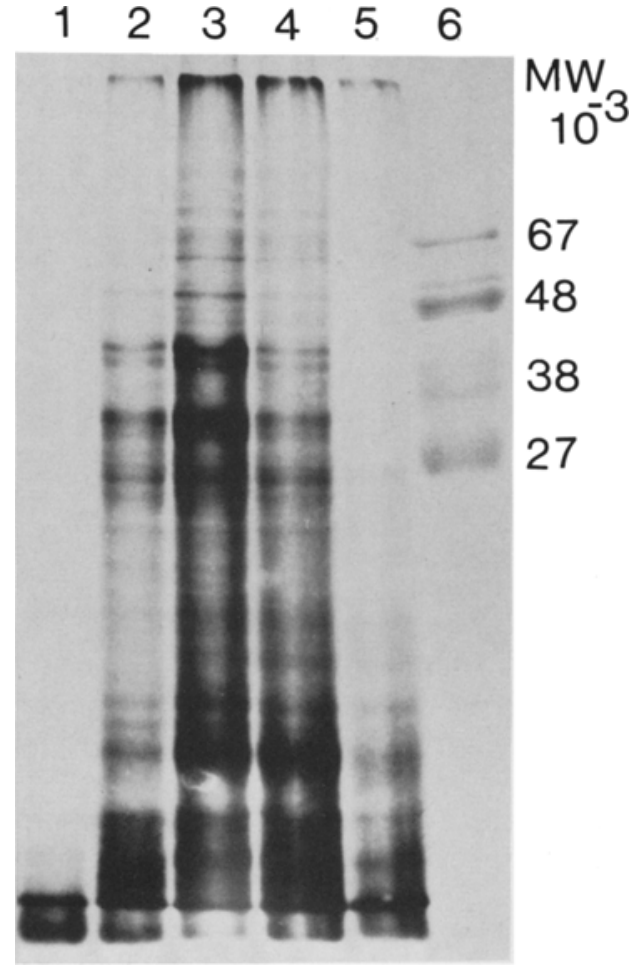

Figure 7: Fluorograms of translation products of mRNA isolated from Bomi and mutant No. 1508 endosperms.

Track 1: In vitro ${ }^{35} \mathrm{~S}$-methionine labelling in the wheat germ cell free protein synthesizing system without added RNA (control).

Track 2: In vitro ${ }^{35}$ S-methionine labelled polypeptides using non-poly-adenylated total cellular RNA from Bomi endosperms as template.

Track 3: In vitro ${ }^{35} \mathrm{~S}$-methionine labelled polypeptides using polyadenylated total cellular RNA from Bomi endosperms as template.

Track 4: In vitro ${ }^{35} \mathrm{~S}$-methionine labelled polypeptides using RNA isolated from initially membrane bound Bomi polysomes as template.

Track 5: In vitro ${ }^{35}$ S-methionine labelled polypeptides using RNA isolated from initially membrane bound mutant No. 1508 polysomes as template.

Track 6: In vivo ${ }^{14} \mathrm{C}$-labelled hordein marker polypeptides.

Figure 5. Isolation of 11S mRNA from barley endosperms of Bomi and its mutant No. 1508 by sucrose gradient sedimentation. RNA retained on Poly(U)-Sepharose 4B columns was eluted and then separated on $5-20 \%$ sucrose gradients. After the centrifugation fractions were collected, the RNA was precipitated with ethanol and then dissolved in $\mathrm{H}_{2} \mathrm{O}$. An aliquot of this RNA was hybridized to ${ }^{3} \mathrm{H}$-polyuridylic acid and RNAase resistent radioactivity determined. Another portion of the RNA was used for analysis of template activity in the wheat germ cell free protein synthesizing system using ${ }^{35} S$-methionine as label. 
indicates a large portion of the incorporated ${ }^{35} \mathrm{~S}$-methionine to be present in low molecular weight peptides which is interpreted to indicate premature chain termination in the translational system.

In tracks 3 and 4 of Figure 6 a comparison is made between the native labelled hordein polypeptides and the $55 \%$ isopropanol soluble translation products of $11 \mathrm{~S}$ polyadenylated RNA from the sucrose gradient of Figure 5A. The translation products of the 11S RNA (track 4) contain 3 groups of bands with apparent molecular weights slightly higher than those of the three groups of native hordein bands. The latter are characterized by the presence of polypeptides with molecular weights at 27, 38 and 48 kilodalton. Faint bands with a molecular weight greater than 67 kilodalton were occasionally seen among the translation products of messenger RNA.

In tracks 5 and 6 of Figure 6 a comparison is made between $55 \%$ isopropanol soluble translation products of 11S RNA and of initially membrane bound polysomes. The latter preparation yielded bands very similar if not identical with those of native hordein, allthough the 67 kilodalton band was faint. A comparison of tracks 4 and 5 with those of 3 and 6 indicates that the translation of isolated messenger RNA gives hordein polypeptides with a larger molecular weight than those of native hordein. The initially membrane bound polysome preparations apparently contain the components necessary for the processing of these hordein precursor molecules.

The improved sharpness of the polypeptide bands in track 5 (Figure 6) compared to those in track 4 is due to the different extraction procedures of the translation products. In the former case the products were first precipitated with TCA and then extracted with 55\% isopropanol, whereas the latter extraction was done directly with $55 \%$ isopropanol. It is evident that lower molecular weight peptides are extracted after translation of purified messenger RNA and polysomes in the protein synthesizing system as was the case with the total RNA preparation (track 2). The hordein precursors found after translaton of purified messenger RNA are predominant among the TCA precipitable translation products from total RNA (compare tracks 4 and 5 with 2).

Identical translation products were obtained when total cellular RNA and total cellular polyadenylated RNA were used as templates in the wheat germ cell free protein synthesizing system (compare Figure 6, track 2 with Figure 7 , track 3). Comparing tracks 2, 3, and 4 of Figure 7, it is evident that the total cellular non-polyadenylated RNA (track 2), total cellular polyadenylated RNA (track 3) and unfractionated RNA from initially membrane bound polysomes (track 4) from Bomi endosperms contain messenger RNA templates coding for polypeptides with identical apparent molecular weights.

The prominent polypeptides in these patterns are $55 \%$ isopropanol soluble (cf. Figure 6, tracks 4 and 5) and it is therefore concluded that all messenger RNA preparations used contain hordein template activity.

When, however, RNA from initially membrane bound polysomes of mutant No. 1508 was used to direct in vitro protein synthesis (track 5) only very faint polypeptide bands were present in the same apparent molecular weight range as the hordein precursors made on wild type templates.

The $11 \mathrm{~S}$ messenger RNA from Bomi endosperms isolated by sucrose gradient sedimentation (Figure 5A) coded for polypeptides identified as hordein precursors. Figure 8 shows an experiment to determine whether a separation of different messenger RNA molecules for hordein polypeptides is possible. The translation products of fractions of a sucrose gradient were analyzed by electrophoresis and the products from 6 fractions are shown in tracks 2-7. The 11S peak of this gradient corresponds to fractions 7 and 8 (tracks 5,6 ) and significant amounts of hordein precursor bands were only present in fractions 7 to 9 . Figure 8 illustrates that no separation of the hordein messenger RNA was achieved.

In a comparable experiment with 11S-RNA from mutant No. 1508 endosperms only a small amount of one polypeptide with an apparent molecular weight of 30 kilodalton could be recognized (Figure 8 , track 9). It corresponds to the precursor of the 27 kilodalton hordein 
band. It is therefore concluded that the IIS mRNA preparations from mutant No. 1508 endosperms either lack messenger RNA for the hordein precursors with molecular weights higher than 30 kilodalton or contain untranslatable messenger RNA.
3.4. Gel electrophoresis of the hordein messenger RNA containing fractions

Agarose-polyacrylamide gel electrophoresis of $20 \mu \mathrm{g}$ RNA from initially membrane bound polysomes from Bomi endosperms revealed the

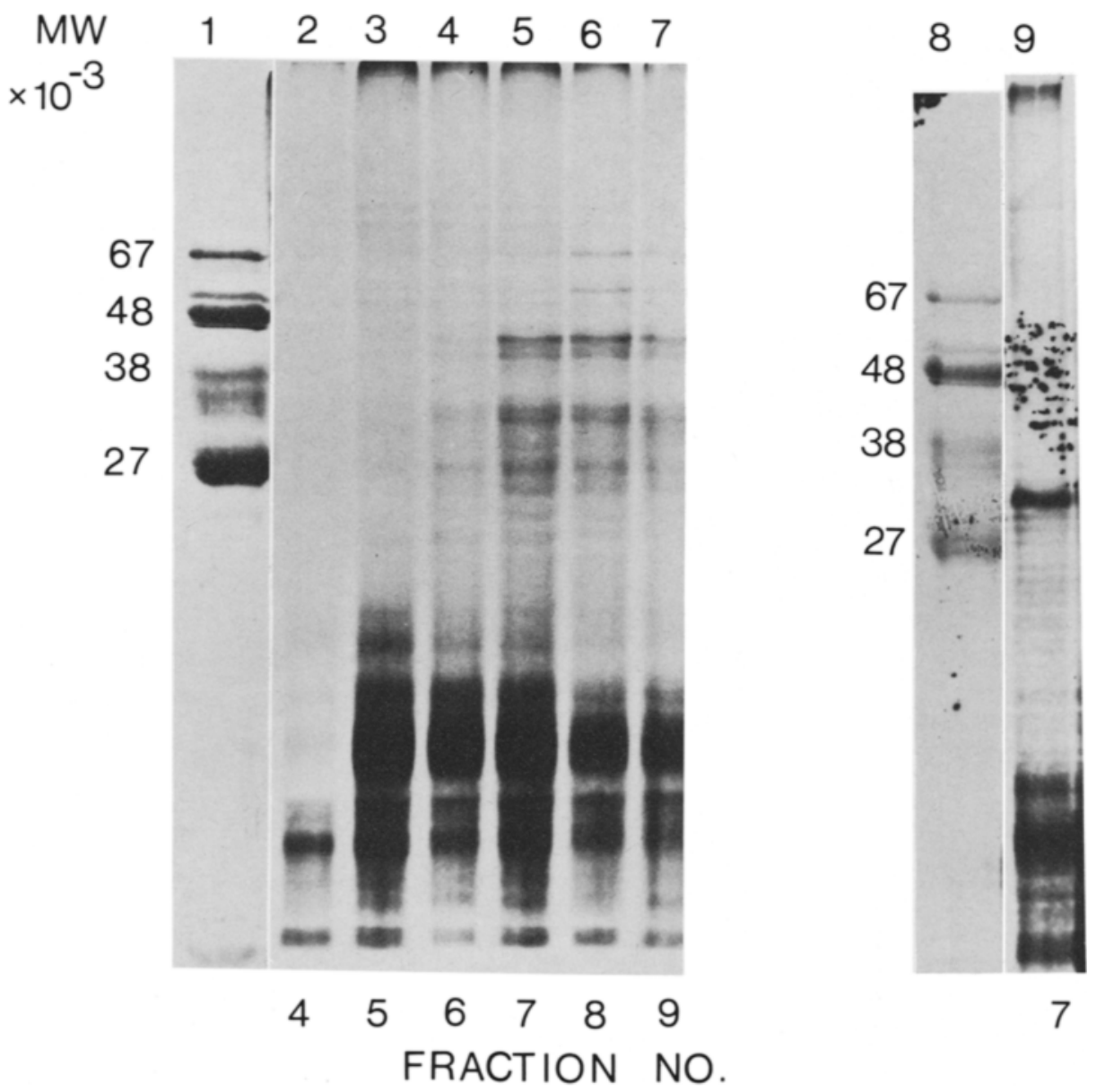

Figure 8: Fluorograms of translation products of polyadenylated mRNA isolated from endosperms of Bomi and its mutant No. 1508. The RNA fractions were obtained by sucrose gradient sedimentation as shown in Figure 6 .

Tracks 1 \& 8: In vivo ${ }^{14} \mathrm{C}$-labelled hordein marker polypeptides.

Tracks 2-7: In vitro ${ }^{35} \mathrm{~S}$-methionine labelled polypeptides using Bomi mRNA fractionated on sucrose gradients as template. (Exposure of fluorogram $24 \mathrm{hrs}$ ).

Track 9: In vitro ${ }^{39} \mathrm{~S}-\mathrm{m}$ ethionine labelled polypeptides using mutant No. $1508 \mathrm{mRNA}$ as template. (Exposure of fluorogram 7 days). 
$26 \mathrm{~S}$ and $18 \mathrm{~S}$ ribosomal RNA molecules to be the major constituents (Figure 9, track 2), whereas the 26S RNA only comprises a minor

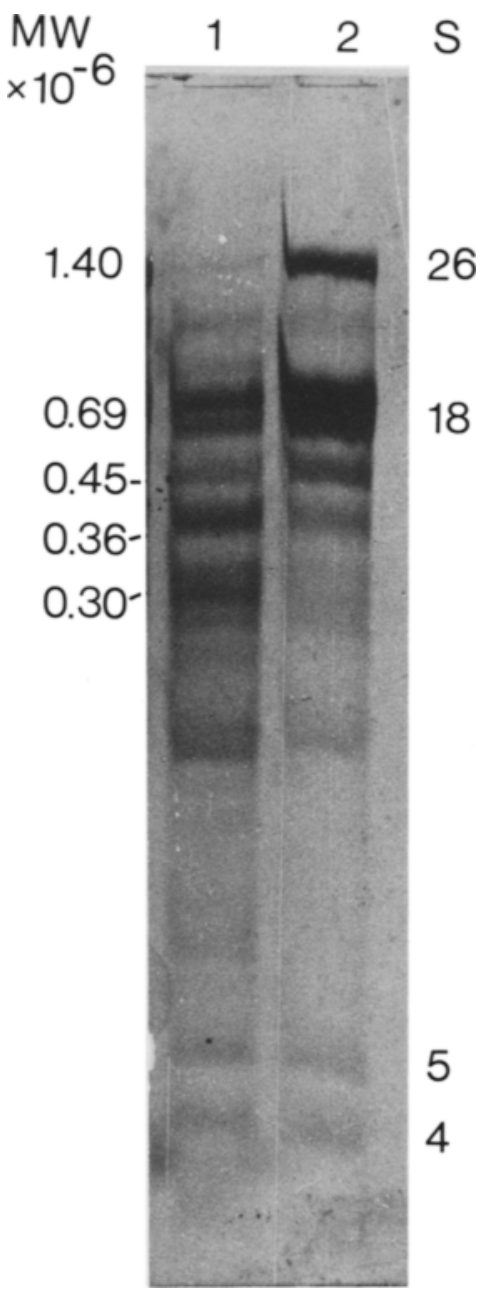

Figure 9. Electrophoretic separation of RNA isolated from initially membrane bound polysomes on a composite agarose-polyacrylamide gel.

Track 1: RNA from mutant No. 1508 endosperms.

Track 2: RNA from Bomi endosperms.

The bands were visualized by methylene-blue staining. The apparent molecular weights were obtained by using as markers ribosomal RNA from E.coli and plant cytoplasmic ribosomes. The $26 \mathrm{~S}$ and $18 \mathrm{~S}$ bands are ribosomal RNA from barley. The faster migrating bands are of the size seen in the fractions containing template activity. The $5 \mathrm{~S}$ and $4 \mathrm{~S}$ bands are considered ribosomal RNA and transfer RNA, respectively. part of the $20 \mu \mathrm{g}$ RNA from mutant No. 1508 endosperms (Figure 9, track 1). On the other hand, the RNA from mutant No. 1508 contained a larger portion of RNA migrating faster than the $18 \mathrm{~S}$ ribosomal RNA.

Gel electrophoresis was also used to analyze the RNA fractions obtained by Sepharose 4B gel filtration of RNA from initially membrane bound polysomes from Bomi endosperms (cf. Figure 4). As seen in Figure 10 an enrichment of four RNA species migrating faster than $18 \mathrm{~S}$ ribosomal RNA was observed in the column fractions 15 and 16 as compared to fractions 12 , 13 or 18,20 . The fractions 15 and 16 contained the major template activity as well as the peak for polyadenylated RNA. This provides evidence that the hordein messenger RNA's are represented among these RNA species and most likely among those with apparent molecular weights of $0.45,0.36$ and 0.30 megadaltons. Further evidence for the size of the hordein messenger RNA was obtained through electrophoretic analysis of RNA from the sucrose gradient fractions (Figure 11). Fraction 7 in track 2 of Figure 11 contains the polyadenylated $11 \mathrm{~S}$ RNA practically free from $18 \mathrm{~S}$ and $26 \mathrm{~S}$ ribosomal RNA and with three major bands of apparent molecular weights of 0.45 , 0.36 and 0.30 megadaltons. $18 \mathrm{~S}$ ribosomal RNA is a major constituent of fraction 11 (track 3), whereas the $26 \mathrm{~S}$ ribosomal RNA dominates in fractions 14 and 17 (tracks 4, 5).

For determination of the molecular weight of the hordein messenger RNA preparative gel electrophoresis was performed with RNA from initially membrane bound polysomes of Bomi endosperms (Materials and Methods 2.9.) The $55 \%$ isopropanol soluble translation products of the RNA extracted from the different gel regions are presented in the densitometer tracings of Figure 12. Only the RNA contained in fraction 5 had significant template activity for hordein polypeptides. This fraction contained $2 / 3$ of the total template activity recovered from the gel sections, emphasizing the abundance of translatable hordein messenger RNA in the developing barley endosperm. This region of the gel covered the apparent molecular weight range from $0.5-0.3$ megadaltons. If hordein messenger RNA is indicated by the stained 
bands of Figure 12, Figure 10 tracks 3, 4 and Figure 11 track 2, the molecular weight of hordein messenger RNA molecules can be estimated to be $0.45,0.36$ and 0.30 megadaltons.
Most eucaryotic messenger RNA molecules contain at their $5^{\prime}$ end a 7-methylguanosine5 -triphosphate structure (CAP) of importance for the initiation of translation (21). The 11S hordein messenger RNA directed protein syn-

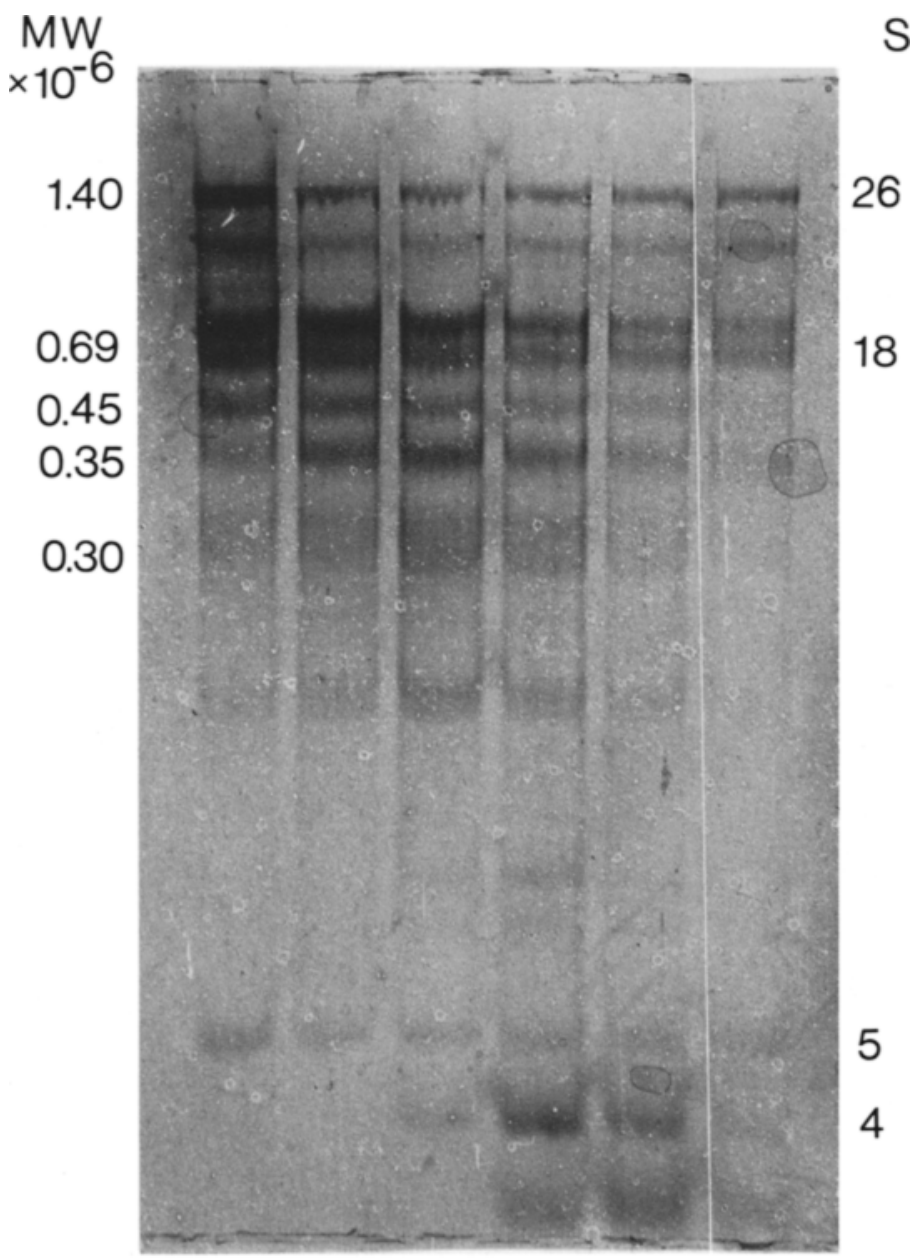

$\begin{array}{llllll}12 & 13 & 15 & 16 & 18 & 20\end{array}$

\section{FRACTION NO.}

Figure 10. Electrophoretic analysis of RNA isolated from initially membrane bound polysomes of Bomi endosperms and fractionated by Sepharose 4B chromatography (cf. Figure 5). Fractions 13 to 16 which contained the high template activity for hordein were enriched in the bands migrating somewhat faster than the $18 \mathrm{~S}$ ribosomal RNA. 

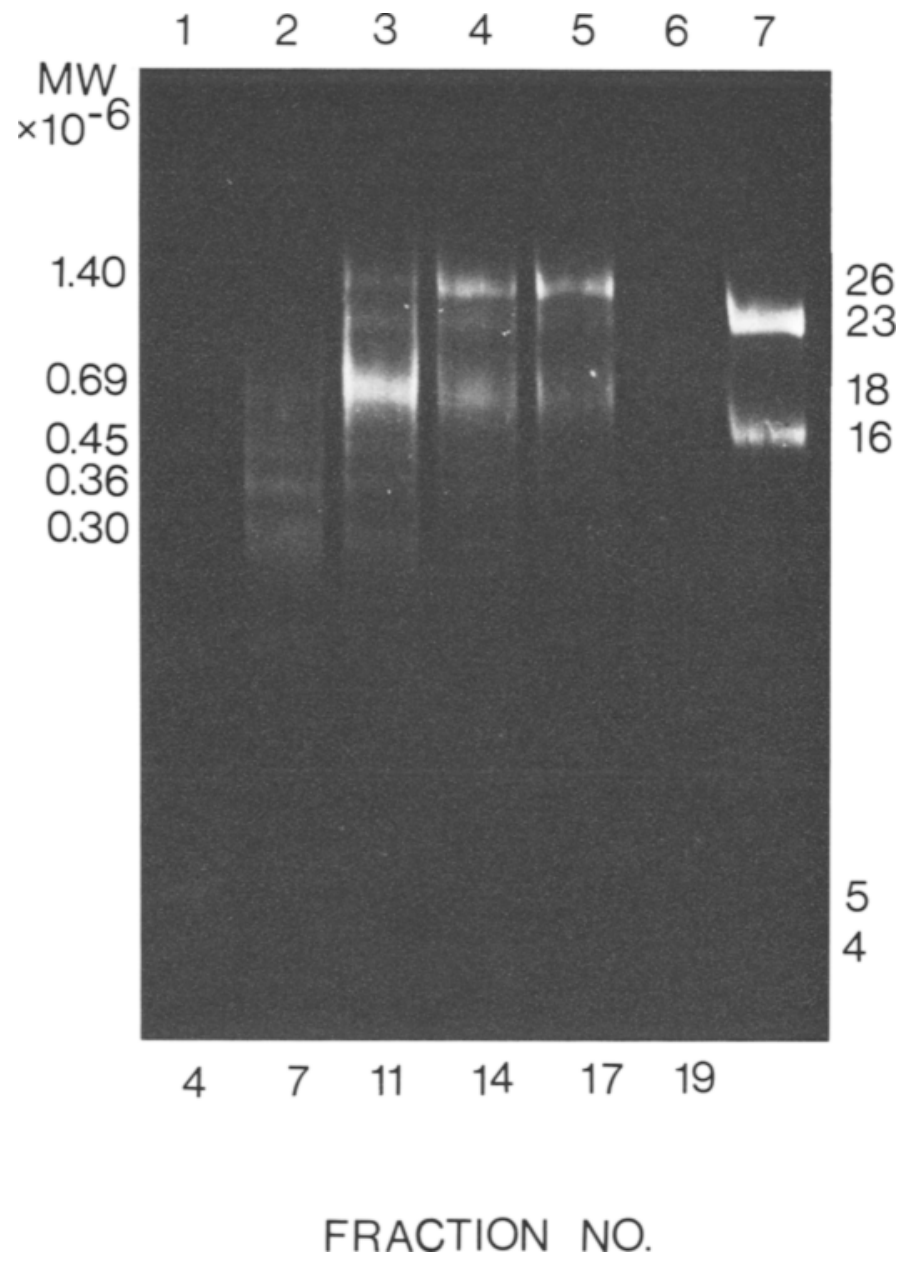

Figure 11. Electrophoretic analysis of polyadenylated RNA from Bomi endosperms on a composite agarosepolyacrylamide gel. The RNA was fractionated by sucrose gradient sedimentation and made visible on the gels by staining with ethidium bromide.

Tracks 1-6: RNA fractions from a sucrose gradient (cf. Figure 6). The template activity for hordein was highest in fraction 7 as evident from the polypeptide analysis of this fraction in Figure 9. This fraction is also relatively free from ribosomal RNA.

Track 7: E.coli ribosomal RNA marker. 


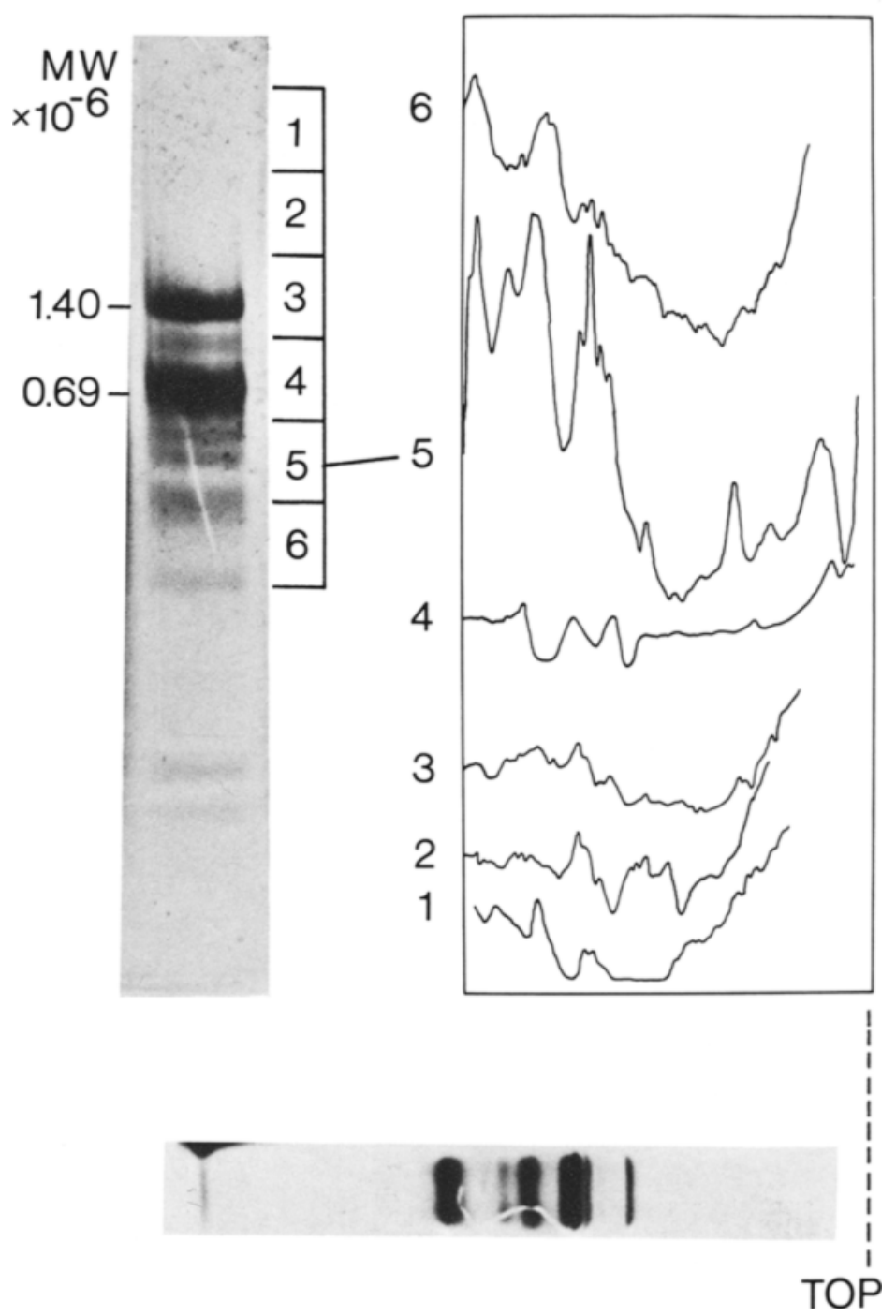

Figure 12. Densitometric tracings of fluorograms from in vitro ${ }^{35} \mathrm{~S}$-methionine labelled polypeptides made with RNA fractionated by preparative gel electrophoresis.

RNA isolated from initially membrane bound polysomes from Bomi endosperms was separated on a composite agarose-polyacrylamide gel (left). The RNA was extracted from gel sections 1 to 6 and purified by oligo(dT)cellulose affinity chromatography. The polyadenylated RNA was used as template in the wheat germ cell free protein synthesizing system. In vivo ${ }^{14} \mathrm{C}$-labelled hordein marker polypeptides are presented at the bottom. Significant template activity for hordein is only observed with RNA fraction 5. 
thesis was $95 \%$ inhibited by $0.4 \mathrm{~mm}-7$ methylguanosine- $5^{\prime}$ monophosphate, an analogue to the (CAP) structure (Figure 13). Hordein messenger thus appears to have this characteristic property. The polyadenylated sequences are found at the $3^{\prime}$ end (16). The $11 \mathrm{~S}$ hordein messenger was titrated against a fixed amount of ${ }^{3} \mathrm{H}$-polyuridylic acid which was calibrated with increasing amounts of polyadenylic acid (Figure 14). Five percent of the messenger residues consisted of a continuous segment of adenine nucleotides. For the three hordein messenger size estimates this amounts to about 70,60 and 50 residues, respectively.

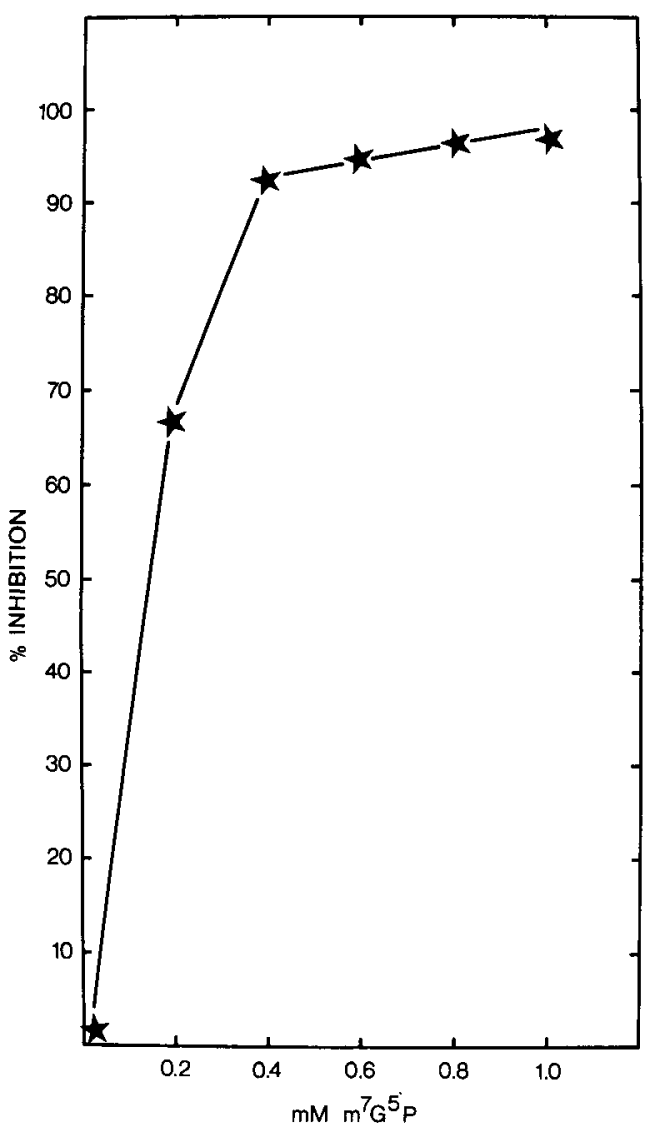

Figure 13. Increasing concentrations of 7-methylguanosine- 5 -phosphate inhibit in vitro protein synthesis directed by $11 \mathrm{~S}$ polyadenylated RNA. The RNA was isolated from initially membrane bound polysomes of Bomi endosperms and incorporation of ${ }^{3 s} \mathrm{~S}$-methionine into $10 \%$ hot TCA insoluble material was measured.

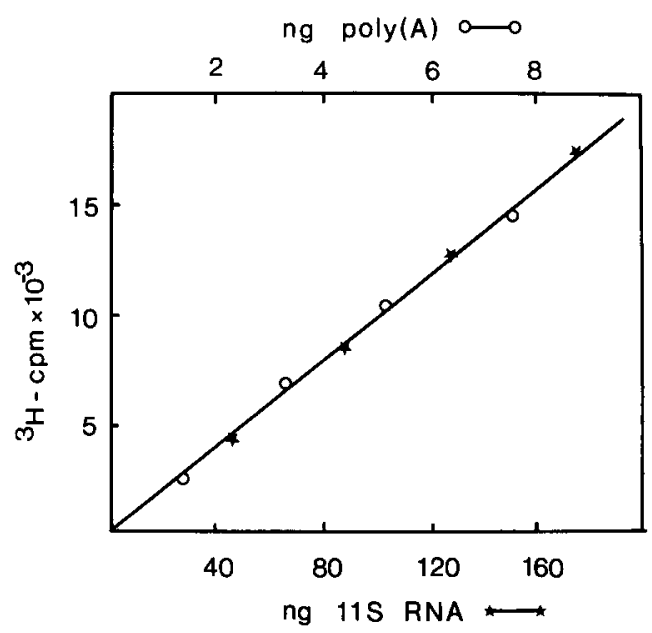

Figure 14. Estimation of the amount of polyadenyl s zquences in a Bomi IIS mRNA isolated by sucrose gradient sedimentation. Increasing amounts of $11 \mathrm{~S}$ mRNA and polyadenylic acid were hybridized to a given amount of ${ }^{3} \mathrm{H}$-polyuridylic acid (cf. 2.10.) and the radioactivity of the hybrids was determined. The 11 RNA contains $5 \%$ polyadenyl sequences.

\section{DISCUSSION}

The similar polypeptide pattern obtained when using wild type total cellular and polysomal 11S RNA as templates for in vitro protein synthesis reveals that a major part of the endosperm messenger RNA population is involved in the synthesis of a group of polypeptides which have the characteristic properties of hordein. We have previously shown that the isopropanol soluble polypeptides made on a membrane bound polysomal template comigrate with native hordein polypeptides (7). The major ${ }^{33} \mathrm{~S}$-methionine labelled polypeptides made on the isolated RNA template from the wild type barley endosperm were soluble in $55 \%$ isopropanol, whereas only little label was found in these polypeptides when RNA templates from mutant 1508 was used.

The small subunit of ribulose-1,5-bisphosphate carboxylase synthesized in vitro with RNA templates isolated from the cytoplasm of pea seedling leaves $(11,22)$ or Chlamydomonas reinhardtii cells (15) has a molecular weight of 20 kilodalton, whereas the native subunit from the chloroplast with 14 kilodalton is smaller. This protein is synthesized on cytoplasmic polysomes which are not attached to the mem- 
branes of the endoplasmic reticulum. The precursor molecules have to move across the two membranes of the chloroplast envelope, where the processing of the precursor to the final size of the small subunit occurs (22). It may be inferred that the mechanism for synthesis, transport and processing of the small subunit of ribulose 1,5-bisphosphate carboxylase is quite different from the membrane bound synthesis and subsequent processing of secretory proteins including the barley endosperm hordein.

The hordein polypeptides produced with purified template were 2 kilodalton larger than native hordein polypeptides, whereas translation products of the initially membrane bound polysomes were similar in size to native hordein. In the wheat germ cell free protein synthesizing system, the only presently known post-translational modification concerns the removal of the N-terminal methionine $(9,28)$. In animal cells, secretory proteins have been shown to be synthesized on the endoplasmic reticulum as larger sized precursors with an extra sequence of approximately 20 amino acids at their $\mathrm{N}$-terminal end (14). The extra amino acid sequence is cleaved off as the polypeptide moves into the lumen of the endoplasmic reticulum (5). It is likely that the mechanism of synthesis, processing and transport of the hordein polypeptides resembles the scheme outlined for animal secretory proteins, since the hordein polypeptides are synthesized on the endoplasmic reticulum, are transported across the membrane into the lumen of the endoplasmic reticulum (10) and are deposited in protein bodies located in vacuoles of the developing barley endosperm $(26,31)$. The larger sized in vitro synthesized hordein polypeptides are likely to contain an additional $\mathrm{N}$ terminal sequence essential for their transport across the endoplasmic reticulum membrane. BurR, BurR, RUbENSTEIN and Simon (8) have presented evidence that the maize endosperm storage protein polypeptides, collectively called zein, are synthesized in vitro in the form of larger sized precursors.

Three distinct RNA bands differing in molecular weights were recognizable in the purified $11 \mathrm{~S}$ messenger RNA fraction isolated from the wild type barley endosperm. The apparent molecular weights of these RNA bands correspond to 1450,1150 and 950 nucleotides, respectively. The coding capacity of RNA molecules of these sizes could generate polypeptides with molecular weights of 53,000 , 42,000 and 35,000 daltons. The recognizable hordein precursor polypeptides synthesized in vitro on the $11 \mathrm{~S}$ template have approximate molecular weights of 50,40 and 30 kilodaltons. Such polypeptides would require a code of approximately 1400,1100 and 800 nucleotides. The recognizable RNA bands are thus in the right size range. The three groups of hordein polypeptides can be resolved into two or more protein bands. Two similar sized messenger RNA's could be present in each RNA band or alternatively, one messenger RNA could be present, containing the coding sequence for both polypeptides. Presence of an amber codon (UAG) near the $3^{\prime}$ end of the coding sequence would by partial read through (34), generate polypeptides only differing little in molecular weights. Partial read through of an amber codon has been shown to occur when tobacco mosaic virus RNA is translated in cell free systems generating two polypeptides from the same initiation point on the RNA (34).

It was possible to isolate significant amounts of polyadenylated 1IS RNA from mutant No. 1508. The RNA could be translated with low efficiency into only one of the hordein precursor polypeptides. At this point it is not possible to determine whether large amounts of untranslatable hordein messenger RNA are made in the mutant endosperm.

We have previously shown that the total polysomal populations were quite similar in the two genotypes when analyzed by sucrose gradient sedimentation and electron microscopy (6). Sucrose gradient analyses presented in this paper of the membrane bound polysomes, demonstrated a two fold increase in the monosome region as well as a decrease in the amount of material in the polysome region of the gradient in the mutant compared to the wild type. This indicates an abnormality in the organization of the membrane bound polysomes of the mutant. The $18 \mathrm{~S}$ and $26 \mathrm{~S}$ ribosomal RNA's constitute a major portion of the total cellular RNA in both genotypes as well 
as of the membrane bound RNA in the wild type endosperm. In contrast, only small amounts of 26S ribosomal RNA were present in the membrane bound RNA from the mutant endosperm. A membrane factor from reticulocyte membranes has been demonstrated to make specific cuts in the $28 \mathrm{~S}$ ribosomal RNA thus inhibiting protein synthesis at the level of elongation (42). In analogy, it is temping to suggest, a factor of similar nature present in the mutant endosperm membranes at later stages of development. However, preliminary experiments have not demonstrated the presence of a specific nuclease activity for the $26 \mathrm{~S}$ ribosomal RNA in Triton X-100 extracts from the membranes of the mutant endosperm.

\section{ACKNOWLEDGEMENTS}

We thank professor DITER voN WETTSTEIN for helpful discussions and critical reading of the manuscript. We also thank Ms. NINA RASMUSSEN for drawing the figures, Ms. ANN-SOFI STEINHOLZ for photography and Ms. INGE HAUGBøLLE SOMMER for typing the manuscript. ANDERS B RANDT acknowledges the receipt of a fellowship from the Ris $\varnothing$ National Laboratory.

\section{REFERENCES}

1. APPEL, K \& K. KLOPPSTECH: The plastid membranes of barley (Hordeum vulgare). Light induced appearance of mRNA coding for the apoprotein of the light-harvesting chlorophyll $\mathrm{a} / \mathrm{b}$ protein. Eur. J. Biochem. 85, 581-588 (1978)

2. ATKINS, J. F., J. B. LEWIS, C. W. ANDERSON \& R. F. GESTELAND: Enhanced differential synthesis of proteins in a mammalian cell-free system by addition of polyamines. J. Biol. Chem. 250, 5688-5695 (1975)

3. Aviv, H. \& P. Leder: Purification of biological active globin messenger RNA by chromatography on oligothymidylic acid cellulose. Proc. Nat. Acad. Sci (USA) 69, 1408-1411 (1972)

4. BONNER, W. M. \& R. A. LASKEY: A film detection method for tritium-labelled proteins and nucleic acids in polyacrylamide gels. Eur. J. Biochem. 46, 83-88 (1974)

5. BLobel, G. \& B. Dobberstein: Transfer of proteins across membranes. I. Presence of proteo- lytically processed and unprocessed immunoglobulin light chains on membrane-bound ribosomes of Murine myeloma. J.Cell Biol. 67, 835-851 (1976)

6. BRANDT, A.: Endosperm protein formation during kernel development of wild type and a high-lysine barley mutant. Cereal Chem. 53, 890-901 (1976)

7. BRANDT, A. \& J. INGVERSEN: In vitro synthesis of barley endosperm proteins on wild type and mutant templates. Carlsberg Res. Commun. 41, 312-320(1976)

8. Burr, B., F. A. Burr, I Rubenstein \& N. N. SIMON: Purification and translation of zein messenger RNA from maize endosperm protein bodies. Proc. Nat. Acad. Sci. (USA) 75, 696-700 (1978)

9. Burstein, Y., F. KAnter \& I. SChechter: Partial amino acid sequence of the precursor of an immunoglobulin light chain containing $\mathrm{NH}_{2}$-terminal pyroglutamic acid. Proc. Nat. Acad. Sci. (USA) 73, 2604-2608 (1976)

10. Cameron-Mills, V., J. Ingversen \& A. Brandt: Transfer of in vitro synthesized barley endosperm proteins into the lumen of the endoplasmic reticulum. Carlsberg Res. Commun. 43, 91-102 (1978)

11. Cashmore, A. R., M. K. Broadhurst \& R. E. GRAY: Cell free synthesis of leaf protein: Identification of an apparent precursor of the small subunit of ribulose 1,5-bisphosphate carboxylase. Proc. Nat. Acad. Sci. (USA) 75, 655-659 (1978)

12. ChuA, N. H. and P. Bennoun: Thylakoid membrane polypeptides of Chlamydomonas reinhardtii wild type and mutant strains deficient in photosystem II reaction center. Proc. Nat. Acad. Sci. (USA) 72, 2175-2179 (1975)

13. Coen, D. M., B. R. Bedbrook, L. Bogorad \& A. RiCH: Maize chloroplast DNA fragments encoding the large subunit of ribulose bisphosphate carboxylase. Proc. Nat. Acad. Sci. (USA) 74, 5487-5491 (1977)

14. Devillers-Thiery, A., T. Kindt, G. Sheele \& G. BLOBEL: Homology in amino-terminal sequence of precursors to pancreatic secretory proteins. Proc. Nat. Acad. Sci. (USA) 72, 5016-5020 (1975)

15. Dobberstein, B., G. Blobel \& N.-H. Chua: In vitro synthesis and processing of a putative precursor for the small subunit of ribulose 1,5-bisphosphate carboxylase of Chlamydomonas reinhardtii. Proc Nat. Acad. Sci. (USA) 74, 1082-1085 (1977)

16. Esnault, R., G. Trapy \& R. B. van Huystee: Polyadenylated RNA from Vicia faba meristematic root cells. Localization and size estimation 
of the poly(A) segment. Eur. J, Biochem. 60, 83-89 (1975)

17. Fox, J. E., H. M. Pratt, P. R. Shewry \& B. J. MIfLIN: The in vitro synthesis of hordeins with polysomes from normal and high-lysine varieties of barley. In: Nucleic acid and protein synthesis in plants. Paris: Center National de la Recherche Scientifique, pp. $501-509$ (1977)

18. Glisin, V., R. Crkvenjakov \& C. Buys: Ribonucleic acid isolated by cesium chloride centrifugation. Biochem. 13, 2633-2637 (1974)

19. Hall, T. C., M. MA, B. U. Buchbinder, J. W. PYNe, S. M. SUN \& F. A. BLISs: Messenger RNA for Gl protein of French bean seeds. Cell free translation and product characterization. Proc. Nat. Acad. Sci. (USA) 75, 3196-3200 (1978)

20. Hartley, M. R., A. Wheeler \& R. J. Ellis: Protein synthesis in chloroplast. V. Translation of messenger RNA for the large subunit of fraction I protein in heterologous cell-free system. J. Mol. Biol. 91, 67-77 (1975)

21. HICKeY, E., L. WeBER \& C. BUGl.IONI: Inhibition of initiation of protein synthesis by 7-methylguanosine-5'-monophosphate. Proc. Nat. Acad. Sci. (USA) 73, 19-23 (1976)

22. Highfield, P. E. \& R. J. Ellis: Synthesis and transport of the small subunit of chloroplast ribulose bisphosphate carboxylase. Nature 271, 420-424 (1978)

23. Holder, A. A. \& J. INGVersen: Peptide mapping of the major components of in vitro synthesized barley hordeins: Evidence of structural homology. Carlsberg Res. Commun. 43, 177-184 (1978)

24. Howell, S. H., P. Heizman, S. Gelvin \& L. L. WALKER: Identification and properties of the messenger RNA activity in Chlamydomonas reinhardi coding for the large subunit of D-ribulose1,5-bisphosphate carboxylase. Plant Physiol. 59, 464-470 (1977)

25. Hunter, T. \& J. I. Garrels: Characterization of the mRNA for $\alpha-, \beta$ - and $\gamma$-Actin. Cell 12, 767-781 (1977)

26. INGVERSEN, J.: Structure and composition of protein bodies from wild type and high lysine barley endosperm. Hereditas 81, 69-76 (1975)

27. IngVersen, J., B. KøIE \& H. DOLL: Induced seed protein mutant of barley. Experientia 29, 1151-1152(1973)

28. JACKSON, R. \& T. HUNTER: The role of methionine in the initiation of haemoglobin synthesis. Nature 277, 672-676 (1970)

29. KaRlson, K. E.: Linkage studies on a gene for high lysine content in Ris $\varnothing$ barley mutant 1508 . Barley Genetics Newsletter 7, 40-43 (1977)

30. LaRkins, B. A., R. A. Jones \& C. Y. Tsai: Isola- tion and in-vitro translation of zein messenger ribonucleic acid. Bjochem. 15, 5506-5511 (1976)

31. MUNCK, L. \& D. von WetTstein: Effects of genes that change the amino acid composition of barley endosperm. In "Genetic improvement of seed proteins" Proc. of a workshop 17-20 March, 1974. National Academy of Sciences, Washington D. C. pp 71-82 (1976)

32. Oram, R. N., H. Doll \& B. KøIE:Genetics of two storage protein variants in barley. Hereditas 80 , 53-58 (1975)

33. Peacock, A. C. \& C. W. Dingman: Molecular weight estimation and separation of ribonucleic acid by electrophoresis in agarose-acrylamide composite gel. Biochem. 7, 668-674 (1968)

34. Pelham, H. R. B.: Leaky UAG termination codon in tobacco mosaic virus RNA. Nature 272, 469-471 (1978)

35. Pelham, H, R, B. \& R. J. Jackson: An efficient mRNA dependent translation system from reticulocyte lysates. Eur. J. Biochem. 67, 247-256 (1976)

36. RAGG, H., J. SCHRODER \& K. HAHLBROCK: Translation of poly(A)-containing and poly(A)-free messenger RNA for phenylalanine ammonia lyase, a plant specific protein, in a reticulocyte lysate. Biochem. Biophys. Acta 474, 226-233 (1977)

37. Roberts, B. E. \& B. M. Patterson: Efficient translation of tobacco mosaic virus RNA and rabbit globin 9S RNA in a cell free system from commercial wheat germ. Proc. Nat. Acad. Sci. (USA) 70, 2330-2334 (1974)

38. Shapiro, D. J. \& R. T. SChimke: Immunochemical isolation and characterization of ovalbumin messenger ribonucleic acid. J. Biol. Chem. 250, 1759-1764 (1975)

39. Shewry, P. R., H. M. Pratt R. A. Finch \& B. J. MIFLIN: Genetic analysis of hordein polypeptides from single seed of barley. Heredity $40,463-466$ (1978)

40. UllRiCh, S. E. \& R. F. Eslick: Inheritance of the shrunken endosperm character, Sex $3 \mathrm{c}$ of Bomi Ris $\emptyset$ mutant 1508 and its association with lysine content. Barley Genetics Newsletter 7, 66-73 (1977)

41. Verma, D. S. \& A. K. BAL: Intracellular site of synthesis and localization of leghaemoglobin in root nodules. Proc. Nat. Acad. Sci. (USA) 73, 3843-3847 (1976)

42. Wreschner, D., D. Melloul \& M. Herzberg: Interaction between membrane functions and protein synthesis in reticulocytes: Specific cleavage of $28 \mathrm{~S}$ ribosomal RNA by a membrane constituent. Eur. J. Biochem. 85, 233-240 (1978) 